Egypt. J. of Nutrition and Health Vol. 16 No. 1 January (2021)

\title{
A study to compare the effect of milk, licorice and tiger nut on stomach ulcer induced in rats
}

\author{
Ayat, E. Rizk and Akram, M.M. ELanany \\ Department of Special Food and Nutrition, Food Technology Research Institute, \\ Agricultural Research Center, Giza, Egypt.
}

\begin{abstract}
Peptic ulcer is a disease affecting a large number of people, caused by various reasons including, NSAIDs and stress. Acute injury occurs more readily with aspirin. The extracts of milk,tigernut and licorice were evaluated for their activities against aspirin gastric ulcer induced in albino rats. Thirty male albino rats, with an average weight of 155-160g were used divided into five groups.6 rats each.All rats were fed basal diet and given free distilled water.Group (1) was left for the whole period of the study (29 days) as negative (-ve) control. Group (2) received $1 \mathrm{ml}$ aspirin (acetyl salicylic acid) to induce gastric ulcer and left as positive control. The other 3 group received the same dose of aspirin; besides group 3 received milk, Group 4 received tiger nut, Group 5 received licorice as doses of $1 \mathrm{ml} /$ rat each morning before breakfast, These 3 groups showed reduction of total area of the ulcer and accelerated healing. The result has shown an increase in final body weight gain of the rats, reduction of total area of the lesion and accelerated ulcer healing of rats treated with tiger nut,licorice and milk Also, reduced total cholesterol, LDL, triglycerides. while HDL was increased than the control
\end{abstract}

Key word.Pepticulcer,tiger nut, licorice, milk

\section{Introduction}

Milk is commonly recommended as therapy for patients with peptic ulcer. It has long been believed that milk helps in healing ulcer since it alleviates the associated pain. Because milk contains both protein and calcium, and each are stimulants of gastric-acid secretion. A diet with a high milk content is often advised for patients with a duodenal ulcer, perhaps because milk is effective at neutralizing gastric-acid secretion(Doll et al., 1956). However, milk soothes the pain only for the time being as it coats the lining of the digestive tract. In fact, it leads to more damage and pain since it stimulates the secretion of digestive juices. Ulcer patients should not, therefore, turn to a glass of milk to relieve their pain (Kulshreshthaet al., 2017).On the other hand,(Abubakar et al., 2018) demonstrated the potential use of camel milk in reversing the damaging effect of ethanol-induced gastric ulcer and alteration of some biochemical parameters. Hence, the authors suggested that camel milk could be used as a dietary supplement for managing gastric ulcer

Licorice is the root of the legume Glycyrrhiza glabra that grows in varieties in warm areas like the Middle East, Asia and Southern Europe (Deutchet al., 2019).Licorice roots are straight pieces of wrinkled, fibrous wood, which are long and cylindrical and grow horizontally underground. Licorice, from which a sweet flavor can be extracted. One of the better-known folk uses of licorice in Europe has 


\section{Ayat, E. Rizk and Akram, M.M. ELanany}

been in the treatment of gastric ulcer.In earlier work, Bennett et al. (1980) demonstrated the anti-ulcer activity of deglycyrrhizinated licorice formulations using a rat model of aspirin-induced gastric mucosal damage. It has been found that the formulation promotes healing by increasing mucus production and blood supply to the damaged stomach mucosa, thereby enhancing mucosal healing (Da Nagaoet al. 1996).It had been shown that licorice-derived compounds can raise the concentration of prostaglandins in the digestive system that promote mucus secretion from the stomach; it was also by that licorice prolongs the life span of surface cells in the stomach and has an anti-pepsin effect. The combined effect may lead to the healing of ulcers. reported that Licorice has also been shown to help inhibit the growth of potentially harmful intestinal bacteria, such as Helicobacter pylori, through the flavonoids that it has.Adel et al.(2005) reported the anti-pepsin effect of secondary metabolites of licorice which prolongs the life span of surface cells in the stomach. While Masoomeh and Kiarash (2007) reported an anti-ulcerogenic effect of carbenoxolone derived from the root of licorice by inhibiting the secretion of gastrin. It has been explained by raising the concentration of prostaglandins in the digestive system by licorice compound that promote mucus secretion from the stomach. Also, Wittschieetal.,(2009) have demonstrated that Liquorice extract is effective in prevention of adhesion of H.pylori in the gastric mucosa infection and hence prevent gastric ulcer. Furthermore, Momenietal.,(2014) suggested that the G Glabra extracts are as effective in prevention of $\mathrm{H}$. Pylori as bismuth, recommending that the patients who are unable to take bismuth may be effectively treated with Liquorice extract. While Hajiaghamohammadi,et al., (2016) reported that G. glabra has anti-inflammatory, anticancer, and anti-ulcer activity. Addition of licorice to the triple clarithromycin-based regimen increases $\mathrm{H}$. pylori eradication, especially in the presence of peptic ulcer disease.

Nugrohoet al., (2016) studied the effect of Liquorice and a combination of other herbs namely, Pulasari (Alyxiareinwardtii), and Sembung (Blumeabalsamifera) including a mixture of all these were tested in Gastric ulcer induced with Aspirin in rats. The researchers noted the gastric protective effects of these substances. Recently,Mathur et al.,(2019) suggested that the G Glabra extract reduces the inflammation and relieves the ulcers and also it can be used as a prophylactic agent to prevent the peptic ulcer in vulnerable subjects. But Ottenbacher, and blehm (2015)reported that it should be used with caution in patients suffering from cardiovascular disease and/or hypertension.

Tiger-nut (Cyperus esculentus L.) belongs to the division-Magnoliophyta, classliliopsida, order - cyperalesand family-cyperaceae (family) was found to be a cosmopolitan perennial crop of the same genus as the papyrus plant. Common Name: Tiger nut, Egyptian local name: Habb el aziz(Krichène et al., 2016).Tiger-nut has been cultivated since early times (chiefly in south Europe \& West Africa) for its small tuberous rhizomes which are eaten raw or roasted,used as hog feed or pressed for its juice to make a beverage (Belewu, 2007).In many countries, Cyperus esculentus is considered a weed and it is underutilized (Krichène et al., 2016).Tiger nut is not widely used in agriculture; it has been poorly investigated and attracted very little scientific and technological interest, and is not commonly used as a food ingredient which may be due to a number of factors.

Tiger nut (milk/beverage/drink) is a healthy drink with many nutrients. It is a rich source of nutrients such as vitamins $\mathrm{C}$, and $\mathrm{E}$, and minerals such as phosphorus, magnesium, potassium, calcium, iron, and also carbohydrates, unsaturated fats, proteins and some enzymes which help in digestion (It has also the advantage of not containing lactose, casein, sugar or proteins of the milk, or cholesterol and reduces gastric acid production as well as reinforcement of gastric mucosal protection. The nutritional value of tiger nut beverage is, however, insufficient given that its protein content is low, only 6.05\% (Umerie and Enebeli, 1997).Amponsahet al., 2017 ,reported that tiger nut milk is less acidic and will be acceptable to patient with ulcer and other related problems. 


\section{Egypt. J. of Nutrition and Health Vol. 16 No. 1 January (2021)}

Peptic ulcer is a common ailment which has a prevalence rate of about $0.2 \%$ in the population worldwide (Mathur et al., 2019). The symptoms include dysphagia, recurrent vomiting, weight loss, or blood in stools. Gastric mucosal damage leading to ulceration occurs due to stress, (Parmar et al., 1993) use of acetylsalicylic acid (ASA), NSAIDs (Yehiyan et al., 2017. Accordingly, diet therapy has played a key role in the prevention and treatment of Peptic ulcer with the main purpose of recovering and protecting the gastrointestinal lining, improving digestion, relieving pain, and contributing to a satisfactory nutritional status(Moayyedi et al., 2005) and (Reis, 2003). Symptoms may mimic hunger, with pain and burning below the breast bone (Khazaei and Salehi 2006).Currently peptic ulcers are treated using multiple interventions depending upon the etiology. including treating $\mathrm{H}$ pylori infection. Ant-acids are used in milder cases.Avoidance of oral intake of NSAIDs and aspirin,and other gastric irritants also are useful. However,some traditional treatments were also employed which are less effective (Mathur et al., 2019).From the above it is clear that Peptic ulcer is a disease known since antiquity, but there are few studies innovating diet therapy as treatment for this disease.

The objective of this study was to review nutritional therapy of peptic ulcers. it was designed to evaluate the potentials of milk, tiger nut and licorice in the treatment of gastric ulceration and to evaluate the effect of different extracts (milk, tiger nut and licorice) on gastric ulcers in rats.

\section{Materials and Methods}

Cow's Milk,tiger nut and licorice were purchased from local market, Giza. All chemicals used were in reagent grade and purchased from Sigma Company.

Aspirin (acetylsalicylic acid) was obtained from El Gomhoriya Company for pharmaceutical industries.Cairo, Egypt.

Urea,alanine amino transferase and asparate amino transferase kits were obtained from Diagnostic company.

\section{Experimental animals}

Thirty male albino rats, with an average weight of 155-160 g were used in the present study and obtained from the animal house of Food Technology Research Institute, Agriculture Research Centre, Giza, Egypt.

Kits

Urea, serum alanine amino transferase (ALT) and serum aspartate amino transferase (AST) kit were obtained from Diagnostic company.

\section{Gastric ulcer induction}

The basal diet is composed of casein (15\%), sunflower oil (10\%), cellulose (5\%), salt mixture (4\%), vitamin mixture (1\%) and starch (65\%). The composition of the salt mixture used was similar to that proposed by Reeves et al. (1993). The composition of vitamin mixture was similar to that reported by A.O.A.C. (2005).

The animals were fed on a basal diet for 7 days as an adaptation period. To induce gastric ulcer, at the 29th day of experimental period rats were fasted for $24 \mathrm{~h}$ and post-orally gavaged with aspirin (1m/kg body weight), except group 1. Rats were sacrificed later. Blood was collected in tubes and centrifuged at $3000 \mathrm{rpm}$ to obtain serum which kept in a deep-freezer until biological 


\section{Ayat, E. Rizk and Akram, M.M. ELanany}

analysisGurbuzet al.,2003. Eight hours after drug administration, the animals were sacrificed by cervical dislocation and the stomachs were opened (cardiac and pyloric )along the greater curvature. The stomach mucosa were examined for ulcer lesions using a hand lens (x 20 magnification). the rats were fasted for 8 hours before the experiment (Abdulla et al. ,2010),but were allowed free access to drinking water up till 2 hours before the experiment.

The length of lesions on the glandular portion was estimated and summed up to calculate the ulcer index using the method and the $\mathrm{pH}$ values were taken every ten minutes for one The ulcer model was according to the method Ekeanyanwn.etal., (2010). The gastric contents were collected in sterile sample bottles for gastric volume, $\mathrm{pH}$, free acidity and total acidity while the degree of ulceration on the epithelial linings of the stomach was measured

\section{Methods}

Preparation of tiger nut milk extract ( flow chart )

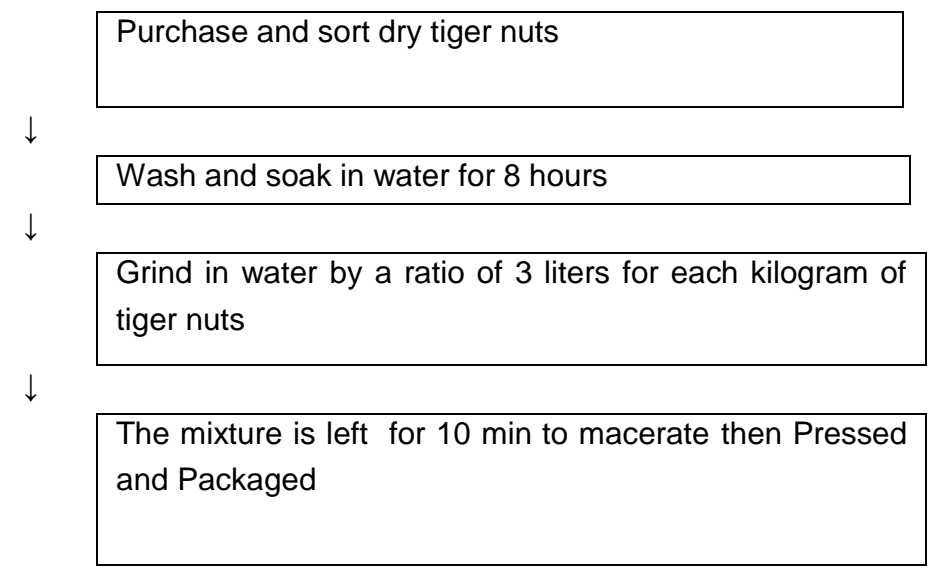

\section{Preparation of licorice extract:}

Ten grm of sample (licorice) were soaked in $250 \mathrm{ml}$ water for $48 \mathrm{hr}$ at room temperature with shaking. mixture was filtered though cheese cloth followed by filter paper,

\section{Experimental design}

The rats were divided into 5 groups six rats each as follow. Group (G1) (negative control) rats received basal diet and distilled water Group (G2) (positive control) rats received basal diet and distilled water for 29 days and received aspirin $500 \mathrm{mg} / \mathrm{kg}$ b.wt orally , Group (G3) rats treated with cow's milk at a dose $2 \mathrm{ml}$ \rat morning, Group (G4) rats orally dosed with tiger nut extract (2ml/rat.pt/ day) and Group (G5) rats were orally given licorice extract ( $2 \mathrm{ml} /$ rat )for 30 days Body weight was recorded and gain weight was calculated at the end of experiment.At the 29 day of experimental period rats fasted for $14 \mathrm{~h}$ and post-orally gavage with aspirin $(500 \mathrm{mg} / \mathrm{kg}$ body weight), The animals were sacrificed $8 \mathrm{~h}$ later. The blood was collected in tubes and centrifuged at $3000 \mathrm{rpm}$ to obtain the serum which kept in a deep-freezer until biochemical analysis.

\section{Gastric Content Parameters}

These are parameters that determine the extent of gastric lesions that occurred in epithelial linings of the gastric walls of the stomach. These parameters include 


\section{Egypt. J. of Nutrition and Health Vol. 16 No. 1 January (2021)}

\section{Measurement length of gastric ulcer}

At the last day of experimental period all rat fasted for $14 \mathrm{~h}$ and only allowed water .the next day all rats were sacrificed and their stomachs were tied around both opening and injected by distilled water $3 \mathrm{ml}$. The gastric contents juice was then collected in sterilized tube the stomachs were opened longitudinally, washed with saline and examined under dissecting microscope for ulcer. The length of gastric ulcers were measured for each group. The curative ratio was then calculated for each group according to the method described by Akhtar (1995) Curative ratio CR\%=(LC-LT/LC) $\times 100$ where LC length of ulcer in control +ve group,LT length of ulcer in treated group

\section{Acidity (measurement the volume of gastric juice}

The stomach was opened to collect the gastric contents. The gastric contents were centrifuged at $1000 \mathrm{rpm}$ for $10 \mathrm{~min}$. Total acidity were determined according to Atta et al,(2005). One $\mathrm{ml}$ of the obtained supernatant was pipetted out and diluted to $10 \mathrm{ml}$ with distilled water. The solution was titrated against $\mathrm{NaOH} 0.01 \mathrm{~N}$ using phenolphthalein as indicator Titration was further continued till the solution regained pink color. The volume of $\mathrm{NaOH}$ required was noted and was taken as corresponding to the total acidity. Acidity was calculated from the following equation

Acidity $(\mathrm{m} \mathrm{Eq} / \mathrm{L})=$ Volume of $\mathrm{NaOH} \times$ Normality $\times 1000$

\section{Ulcer index}

The term ulcer index means the number of ulcers in the gastric walls which is caused by the secretion of strong acid (HCL) and enzymes (pepsin) by the parietal and chief cell respectively. After sacrificing the rats, the stomach were removed and opened along the greater curvature. The severity of hemorrhagic erosions in the acid secreting glandular mucosa were assessed on a scale of 0 to 3 .

$0=$ normal

$1=$ one to four petechiae

2 =five or more petechiae or hemorrhagic streaks up to $4 \mathrm{~mm}$ and

3 =erosions longer than $5 \mathrm{~mm}$ or confluent haemorrhages(Maity, 1993)

\section{Gastric pH}

$\mathrm{pH}$ is equal to $-\log 10$ of hydrogen ion concentration in moles per litre. Gastric $\mathrm{pH}$ is the acidity of the stomach. The parietal cell releases bicarbonate into the blood stream the gastric juice solution on a logarithmic scale on which 7 is neutral, The $\mathrm{pH}$ of gastric acid is 1.5 to 3.5 (Marieband Hoehn, 2010) in the human stomach lumen, the acidity being maintained by the proton pumpH+/K+ ATPase process, which causes a temporary rise of $\mathrm{pH}$ in the blood, known as alkaline tide. The lowest $\mathrm{pH}$ of the secreted acid is 0.8 (Guyton.,and John, 2006)

\section{Histopathological examination of stomachs}

The study was performed at Pathology department, Faculty of Veterinary Medicine, Cairo University. Stomachs of sacrificed rats were taken and immersed in $10 \%(\mathrm{v} / \mathrm{v})$ formalin solution, the fixed specimens were then trimmed, washed and dehydrated in ascending grades of alcohol then, cleared in xylol and embedded in paraffin then sectioned at 4-6 microns thickness and stained with Heamtoxylin and Eosin according to Carleton (1976) 


\section{Ayat, E. Rizk and Akram, M.M. ELanany}

\section{Blood sampling}

Blood samples were collected at the end of the experiment from the eye plexuses by fin capillary glass tubes.sample was collected into both heparinized tubes to obtain the whole blood for determination of hemoglobin and red blood cells and into a dry clean centrifuged glass tube without any coagulant to prepare serum. Blood samples were left for $15 \mathrm{~min}$ at room temperature then tubes were centrifuged for $10 \mathrm{~min}$ at $3000 \mathrm{rpm}$ and kept frozen at $-20^{\circ} \mathrm{C}$ until the biochemical evaluation

\section{Biochemical evaluation}

Total cholesterol in the serum LDL and HDL were determined by kit according to Reitman and Frankel (1957)

\section{Determination of serum urea}

Urea in serum was determined according to the method described by Shephard and Mezzachi(1983)

\section{Statistical analysis}

The data were subjected to statistical analysis using the standard analysis of variance as outlined by (Snedecor and Cocharan 1980)

\section{Results and discussion}

Table (1)

Proximate composition of raw and extract of tiger nut, licorice and Cow's milk $\mathbf{g} \backslash \mathbf{1 0 0} \mathrm{g}$

\begin{tabular}{c|c|c|c|c|c|c}
\hline Parameter & \multicolumn{2}{|c|}{ Tiger nut } & \multicolumn{2}{c|}{ licorice } & \multicolumn{2}{c}{ Cow's milk } \\
\hline & Raw & Extract & Raw & Extract & Raw & Extract \\
\hline Moisture & $5.77 \pm 0.53^{\mathrm{c}}$ & $84.07 \pm 0.53^{\mathrm{a}}$ & $9.03 \pm 1.5^{\mathrm{b}}$ & $88.03 \pm 1.5^{\mathrm{a}}$ & $87.0 \pm 3.30^{\mathrm{a}}$ & $87.0 \pm 3.30^{\mathrm{a}}$ \\
\hline Crude protein & $6.00 \pm 1.55^{\mathrm{c}}$ & $5.00 \pm 0.55^{\mathrm{c}}$ & $6.50 \pm 0.24^{\mathrm{c}}$ & $4.50 \pm 0.24^{\mathrm{b}}$ & $3.80 \pm 0.62^{\mathrm{c}}$ & $3.80 \pm 0.62^{\mathrm{c}}$ \\
\hline Ether extract & $24.0 \pm 2.74^{\mathrm{b}}$ & $2.0 \pm 0.74^{\mathrm{e}}$ & $1.34 \pm 0.54^{\mathrm{e}}$ & $1.04 \pm 0.54^{\mathrm{d}}$ & $3.30 \pm 0.44^{\mathrm{c}}$ & $3.30 \pm 0.44^{\mathrm{d}}$ \\
\hline Total ash & $1.70 \pm 0.33^{\mathrm{e}}$ & $1.20 \pm 0.33 \mathrm{f}$ & $5.40 \pm 1.22^{\mathrm{d}}$ & $1.00 \pm 0.22^{\mathrm{d}}$ & $1.35 \pm 0.01^{\mathrm{d}}$ & $1.35 \pm 0.01^{\mathrm{e}}$ \\
\hline Crude fiber & $4.30 \pm 0.33^{\mathrm{d}}$ & $2.30 \pm 0.33^{\mathrm{d}}$ & $33.00 \pm 3.51^{\mathrm{b}}$ & $2.00 \pm 3.51^{\mathrm{c}}$ & $0.00 \pm 0.00^{\mathrm{e}}$ & $0.00 \pm 0.00^{\mathrm{f}}$ \\
\hline Total carbohydrate & $58.23 \pm 3.56^{\mathrm{a}}$ & $5.43 \pm 0.56^{\mathrm{b}}$ & $44.73 \pm 1.65^{\mathrm{a}}$ & $4.43 \pm 1.65^{\mathrm{b}}$ & $4.55 \pm 0.41^{\mathrm{b}}$ & $4.55 \pm 0.41^{\mathrm{b}}$ \\
\hline
\end{tabular}

Values are means \pm SD of three measurements.

Means in the same column with different letters are significantly different $(p<0.05)$.

Data in table (2) demonstrated that final body weight and weight gain were increased in the rats orally administrated with any of the extracts compared to the control

Table(2)

The effect of Cow's milk,tiger nut extract and licorice extract on the change of body weights of rats.

\begin{tabular}{c|c|c|c}
\hline Group & Initial weight $(\mathrm{g})$ & Final weight $(\mathrm{g})$ & Weight gain(g) \\
\hline G1 & $156 \pm 2.5^{\mathrm{a}}$ & $287 \pm 3.7^{\mathrm{o}}$ & $83 \pm 0.01^{\mathrm{b}}$ \\
\hline G2 & $155 \pm 1.8^{\mathrm{a}}$ & $256 \pm 3.6^{\mathrm{c}}$ & $65 \pm 0.12^{\mathrm{d}}$ \\
\hline G3 & $156 \pm 3.5^{\mathrm{a}}$ & $284 \pm 1.8^{\mathrm{b}}$ & $82 \pm 0.00^{\mathrm{c}}$ \\
\hline G4 & $154 \pm 2.4^{\mathrm{a}}$ & $288 \pm 2.1^{\mathrm{b}}$ & $87 \pm 0.02^{\mathrm{a}}$ \\
\hline G5 & $155 \pm 2.2^{\mathrm{a}}$ & $290 \pm 2.3^{\mathrm{a}}$ & $87 \pm 0.01^{\mathrm{a}}$ \\
\hline
\end{tabular}

Values are means \pm SD of three measurements.

Means in the same column with different letters are significantly different $(p<0.05)$. 


\section{Egypt. J. of Nutrition and Health Vol. 16 No. 1 January (2021)}

The effect of milk, Tiger nut and licorice extracts tested on gastric parameters in albino rats are shown in table (3) The total acidity decreased by all tested milk and plant extracts compared to positive control. The reduction in the total acidity of gastric fluid in ulcerated rats by aspirin may be attributed to the anti-ulcer genic it was found that total acidity, volume of gastric juice and total area were decreased significantly in the rats orally administrated with milk, tiger nut and licorice extracts compared to the control +(control group showed decreased $\mathrm{pH}$ of gastric juice compared to normal control. The severity in terms of volume and total acidity significantly reduced with an increase in $\mathrm{pH}$ values after treatment with milk and the extracts

Table (3)

Effect of oral administration of milk and plant extracts on various gastric fluid parameters in

rats

\begin{tabular}{c|c|c|c|c|c}
\hline Group & pH of gastric juice & Ulcer index $(\mathrm{mm})$ & $\begin{array}{c}\text { Total area } \\
\text { Of lesion }(\mathrm{mm} 2)\end{array}$ & $\begin{array}{c}\text { Volume of gastric } \\
\text { juiceml }\end{array}$ & $\begin{array}{c}\text { Total } \\
\text { Acidity }(\%)\end{array}$ \\
\hline G1 & $5.0 \pm 0.03^{\mathrm{a}}$ & 0 & 0 & $0.5 \pm 0.02^{\mathrm{b}}$ & $14.3 \pm 0.15^{\mathrm{b}}$ \\
\hline $\mathrm{G} 2$ & $0.01 \pm 0.02^{\mathrm{e}}$ & $13.6 \pm 0.54^{\mathrm{a}}$ & $6.30 \pm 0.03^{\mathrm{a}}$ & $1.9 \pm 0.05^{\mathrm{a}}$ & $30.8 \pm 2.3^{\mathrm{a}}$ \\
\hline $\mathrm{G} 3$ & $4.3 \pm 0.04^{\mathrm{d}}$ & $3.5 \pm 0.23^{\mathrm{b}}$ & $2.20 \pm 0.20^{\mathrm{c}}$ & $0.3 \pm 0.01^{\mathrm{d}}$ & $3.8 \pm 0.22^{\mathrm{c}}$ \\
\hline G4 & $4.5 \pm 0.01^{\mathrm{c}}$ & $3.4 \pm 0.55^{\mathrm{b}}$ & $3.2 \pm 0.010^{\mathrm{b}}$ & $0.4 \pm 0.03^{\mathrm{c}}$ & $4.0 \pm 0.12^{\mathrm{c}}$ \\
\hline G5 & $4.8 \pm 0.03^{\mathrm{b}}$ & $3.2 \pm 0.83^{\mathrm{c}}$ & $3.0 \pm 0.010^{\mathrm{b}}$ & $0.5 \pm 0.04^{\mathrm{b}}$ & $3.9 \pm 0.32^{\mathrm{c}}$ \\
\hline
\end{tabular}

Values are means \pm SD of three measurements.

Means in the same column with different letters are significantly different $(p<0.05)$.

The data indicated that ulcer index for the positive control rats was $13.6 \pm 0.54 \mathrm{~mm}$ compared to zero in the negative control rats.Also, the ulcer index decreased by all of the tested extracts, the extract of tiger nut and licorcie had significant highest reduction of the ulcer index $(3.2 \pm 0.83)$ exhibiting a highest protection ratio $(76.47 \%)$ compared with all tested extracts. In reference group, the gastric protective effect of tiger nut extracts is probably due to their content of flavonoids (Atta et al., 2005). pointed out that the compounds with anti ulcer activity include flavonoids, tannins, gums and mucilage.On the other hand, there was a significant increase in total acidity of gastric fluid in the positive control rats compared with the negative control. The total acidity was significantly decreased by all treatment compared to positive control. In addition, the highest reduction in the total acidity of gastric fluid was observed in rats orally administrated with treatment while, treatment of ulcer group with cowmilk,tiger nut and licorice extracts decreased the total area of lesion and acceleration of the ulcer healing

(Ramamurthy.,2012) have reported that inhibition of acid secretion accelerates ulcer healing .The reduction in the total acidity of gastric fluid in ulcerated rats by aspirin may be attributed to the anti-ulcerogenic effects. Tiger nut and licorice extracts displays an anti-ulcer genic and significantly reduced the induced ulcer aspirin results in the gastric lesion and moderately destroyed the architecture of stomach with a clear discontinuity in the mucosa (mild-moderate ulceration). Sippy proposed a diet based on milk, combined with antacids, for treatment of gastrointestinal ulcer, based on the principle that milk would provide gastric alkalization and relieve pain .One of the measures that may contribute to reduce the infection rate by $\mathrm{H}$. pylori is dietary modulation with the addition of probiotics. However, studies on rats indicate that probiotics improve slightly the elimination rate in treatment against $\mathrm{H}$. pylori, being useful to decrease the bacterial load and likely improve dyspeptic symptoms. While tiger nuts have long been recognized for their health benefits as they have a high content of soluble glucose and oleic acid, along with high energy content (starch, fats, sugars and proteins), they are rich in minerals such as phosphorous and potassium, calcium, magnesium and iron 


\section{Ayat, E. Rizk and Akram, M.M. ELanany}

necessary for bones, tissue repair, muscles, the blood stream and for body growth and development and rich in vitamins $\mathrm{E}$ and $\mathrm{C}$, and its high content of Arginine, which liberates the hormone that produces insulin .It is recommended for those who suffer from indigestion, flatulence and diarrhea because it provides digestive enzymes like the catalase, lipase and amylase. The high content of oleic acid has positive effect on cholesterol, Tiger nut reduces the risk of cancer colon.

The effect of tiger nut, licorice extracts and cow milk on plasma lipid profile is listed in table 4 . Total cholesterol, LDL-cholesterol and triglycerides were decreased significantly, while HDLcholesterol was significantly increased, in the rats orally administrated with any of tiger nut, licorice and Cow's milk compared to the control(G2

Table (4)

Effect of oral administration of Cow'smilk,tiger nut and licorice extracts on serum lipid profile of the experimental rats

\begin{tabular}{c|c|c|c|c}
\hline Group & $\begin{array}{c}\mathrm{LDL} \\
(\mathrm{mg} / \mathrm{dl})\end{array}$ & $\begin{array}{c}\mathrm{HDL} \\
(\mathrm{mg} / \mathrm{dl})\end{array}$ & $\begin{array}{c}\text { Total cholesterol } \\
(\mathrm{mgldl})\end{array}$ & $\begin{array}{c}\text { Triglycerides } \\
(\mathrm{mgldl})\end{array}$ \\
\hline $\mathrm{G} 1$ & $20.4 \pm 1.4^{\mathrm{b}}$ & $40.1 \pm 0.3^{\mathrm{e}}$ & $70.2 \pm 0.44^{\mathrm{e}}$ & $45.9 \pm 0.33^{\mathrm{e}}$ \\
\hline G2 & $60.4 \pm 0.6^{\mathrm{a}}$ & $14.5 \pm 3.4^{\dagger}$ & $88.6 \pm 0.20^{\mathrm{a}}$ & $100 \pm 0.52^{\mathrm{a}}$ \\
\hline G3 & $16.7 \pm 0.7^{\mathrm{e}}$ & $42.8 \pm 0.5^{\mathrm{b}}$ & $76.3 \pm 0.16^{\mathrm{b}}$ & $89.3 \pm 0.61^{\mathrm{b}}$ \\
\hline G4 & $17.5 \pm 0.3^{\mathrm{a}}$ & $43.6 \pm 0.3^{\mathrm{a}}$ & $74.8 \pm 0.11^{\mathrm{d}}$ & $88.6 \pm 0.39^{\mathrm{c}}$ \\
\hline G5 & $18.6 \pm 0.2^{\mathrm{c}}$ & $41.2 \pm 0.2^{\mathrm{d}}$ & $75.8 \pm 0.21^{\mathrm{c}}$ & $82.9 \pm 0.25^{\mathrm{d}}$ \\
\hline
\end{tabular}

Values are means \pm SD of three measurements

Means in the same column with different letters are significantly different $(p<0.05$

The results of estimated serum ALT, AST enzymes and urea are presented in Table (5) levels of AST and ALT in G2 were significantly increased in rats (55.2 \pm 2.16 and $63.08 \pm 2.05$, respectively) compared to negative control. Aspirin alone showed acute elevation of serum AST and ALT as indicators of hepatic injury since elevated levels of these hepatocellular enzymes are signs of aspirininduced tissue damage. The increase in the levels of urea indicated deterioration of kidney function. Urea was also increased in rats that received extract of licorice seeds and compared with negative control rats in Group 2 That received a single dose aspirin showed marked elevation of the liver enzymes when compared with those of the group 1 (control) rats. However, the pretreated groups 3, 4, 5 showed significant decline in the levels of AST, ALT when compared with group 2 rats

Table (5)

Effect of oral administration of Cow'smilk and tiger nut and licorice extracts on serum levels of aspartate (AST), alanine (ALT) transaminases $(\mathrm{U} / \mathrm{l})$ and urea $(\mathrm{mg} / \mathrm{dl})$ in rats.

\begin{tabular}{c|c|c|c}
\hline Group & AST(UL) & ALT(UL) & Urea(mg/dl) \\
\hline G1- & $22.5 \pm 2.10^{\mathrm{c}}$ & $18.9 \pm 1.00^{\mathrm{c}}$ & $20.5 \pm 1.55^{\mathrm{e}}$ \\
\hline G 2+ & $55.2 \pm 2.16^{\mathrm{a}}$ & $63.0 \pm 2.05^{\mathrm{a}}$ & $45.3 \pm 2.03^{\mathrm{a}}$ \\
\hline G3 & $23.5 \pm 2.00^{\mathrm{bc}}$ & $20.3 \pm 1.31^{\mathrm{c}}$ & $23.1 \pm 2.76^{\mathrm{d}}$ \\
\hline G4 & $24.3 \pm 2.21^{\mathrm{bc}}$ & $22.2 \pm 0.01^{\mathrm{b}}$ & $26.0 \pm 1.03^{\mathrm{c}}$ \\
\hline G5 & $25.5 \pm 2.32^{\mathrm{b}}$ & $20.0 \pm 2.02^{\mathrm{c}}$ & $28.1 \pm 1.55^{\mathrm{b}}$
\end{tabular}

Values are means \pm SD of three measurements

Means in the same column with different letters are significantly different $(p<0.05$ 


\section{Egypt. J. of Nutrition and Health Vol. 16 No. 1 January (2021)}

\section{Histopathological examination of Stomach:}

Microscopically, stomach of rats from group 1 revealed congestion of submucosal blood vessels (Fig. 1) and submucosal oedema associated with inflammatory cells infiltration. Moreover, stomach of rats from groups 2 showed submucosal oedema and inflammatory cells infiltration (Figs. 2). Meanwhile, stomach from group 4 and 3 revealed the normal histological structure of gastric layers (Figs. 3,4).Group 5 revealed the normal histological structure (Fig.5) (Figs. 3,4,5) and small foca hepatocellular necrosis associated with mononuclear inflammatory cell. showed slight hydropic degeneration This may be attributed to the ability of milk to inhibit osmotic lysis of the red blood cells and also increase the antioxidant defense mechanism of the erythrocyte's membrane. milk is rich in vitamin $E$, Vitamin $E$ helps in maintaining the flexibility of red blood cells which reduce the fragility. We postulate that Licorice and tiger nut could be a prophylactic agent which can prevent the gastric ulcer, if given before the ulcer. (Deutch,et al.,2019) licorice and tiger nut included that the alkalinity of the minerals effectively helps in regulating the boods $\mathrm{pH}$, neutralizing acidity. also tiger nut is soothing for the treatment of gastric and duodenal ulcers. (Narayan et al.,2014).infiltration.that tiger nuts have a relatively high total antioxidant capacity, because they contain considerable amounts of water-soluble flavonoid glycosides and the fact that tiger nut milk is used as liver tonic The results of this study show that pretreatment of rats 30 days preceding tiger nut, licorice and milk administration caused a marked decline in the levels of hepatospecific serum enzymes. This suggests that tiger nuts (Cyperus esculentus) may be protective against aspirin -induced liver damage in rats. This study was conducted to investigate the potential of tiger nut, licorice and milk supplementation in the management of gastric ulcer. This may be attributed to the ability of milk to inhibit osmotic lysis of the red blood cells and also increase the antioxidant defense mechanism of the erythrocytes membrane. milk is rich in vitamin $E$ Vitamin $E$ helps in maintaining the flexibility of red blood cells which reduce the fragility. we postulate that Liquorice could be a prophylactic agent which can prevent the gastric ulcer, if given before the ulcer. 


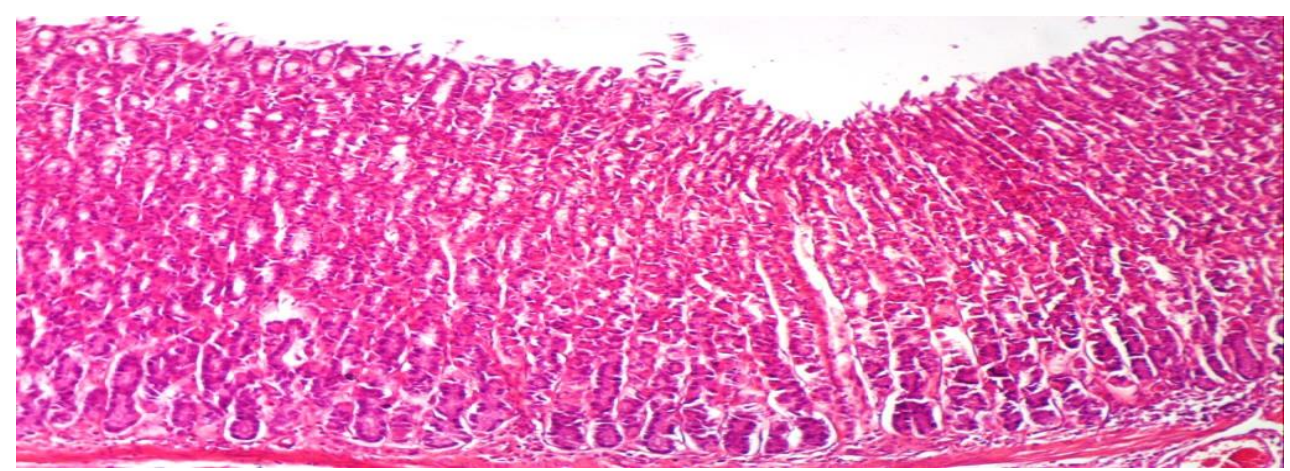

Fig. (1):

Stomach of rat from group2 showing congestion of submucosal blood vessels and submucosal oedema associated with inflammatory cells infiltration (H \& E X 100

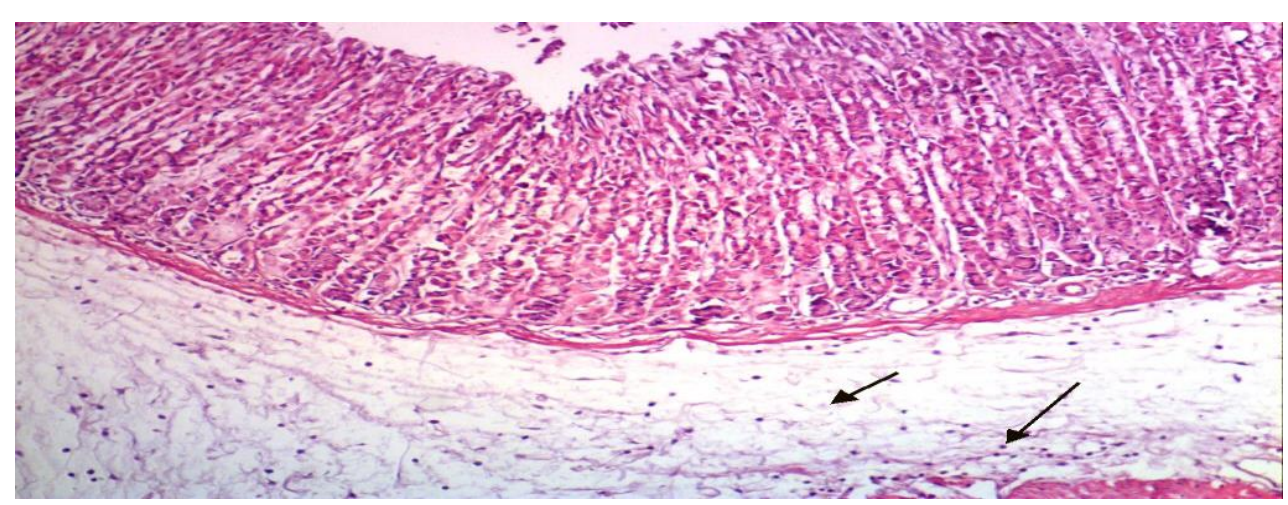

Fig. (2):

Stomach of rat from group 2 showing submucosal oedema and inflammatory cellsinfiltration

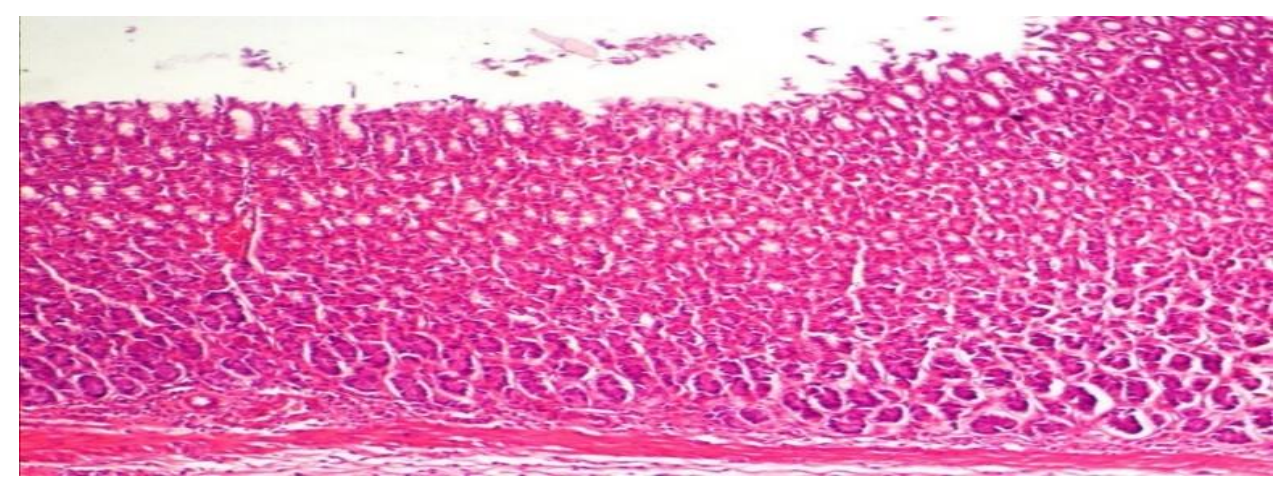

Fig. (3):

Stomach of rat from group 3 (milk) showing normal histological structure of gastric layers 


\section{Egypt. J. of Nutrition and Health Vol. 16 No. 1 January (2021)}

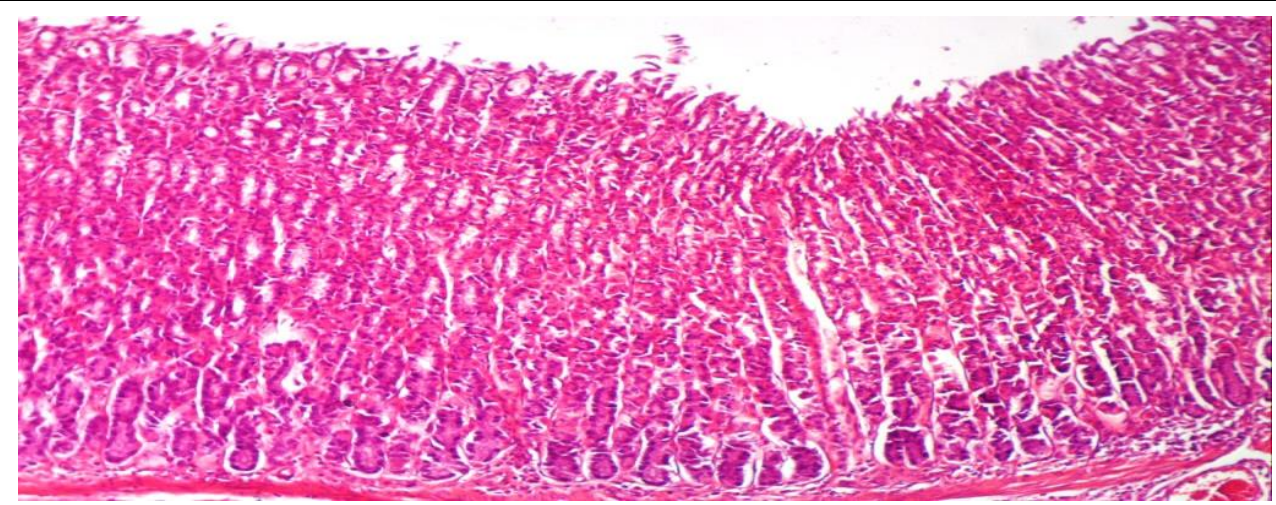

Fig. (4):

Stomach of rat from group 4 (tiger nut) showing the normal histological structure of gastric layers.

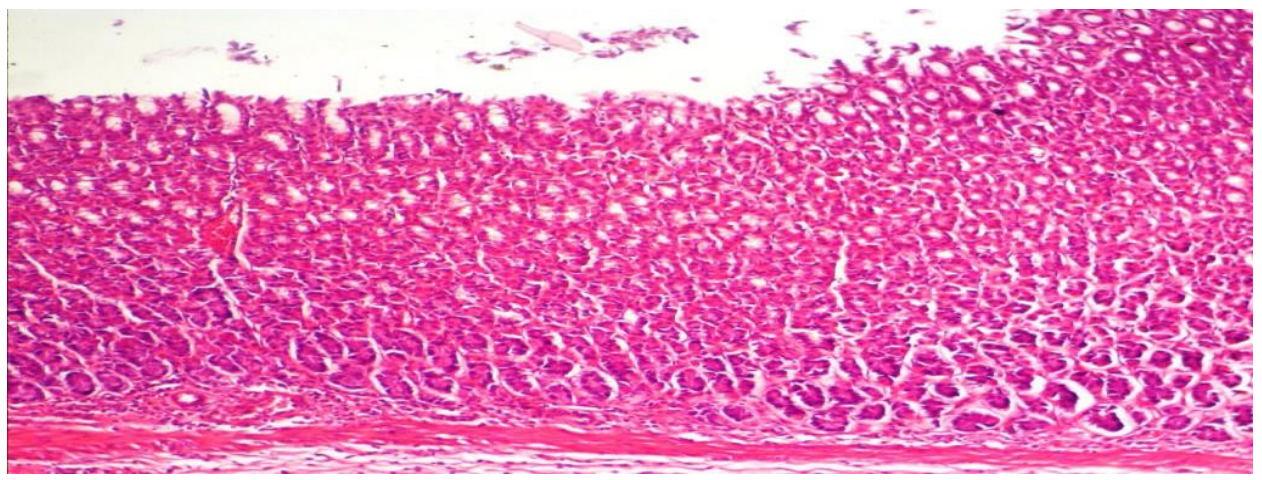

Fig. (5):

Stomach of rat from group 5 (licorice) showing the normal histological structure of gastric layers

Data indicated that tiger nut, milk and licorice significantly had highest reduction of the ulcer index with increment of protection ratio compared with positive group In addition, the total acidity was significantly decreased by all of the tested plant extracts compared with positive control.

\section{conclusion}

From this study we could conclude that water extract of licorice is an effective remedy for the protection of gastric mucosa, in terms of inhibition of acid secretion, healing properties by tissue regeneration and also antioxidant action.and use of milk in reversing the damaging effect, induced gastric ulcer and alteration of some biochemical parameters. Hence milk and tiger nut could be used as a dietary supplement for managing gastric ulcer induced by asprin. 


\section{REFERNCES}

Abdulla,M.A., Ahmed,K.A.,AL-Bayaty,F.H.andMasood,Y.(2010).

Gastroprotective effect of Phyllanthus niruri leaf extract against ethanol-induced gastric mucosal injury in rats .African Journal of Pharmacy and Pharmacology,4(5):226-230.

Abubakar, A. L., Dandare, A., Dandare, S. U., Rabiu, S., Ibrahim, A. S., \&Armaya'u, S. (2018). Effect of camel milk supplementation in management of gastric ulcer. Applied Medical Research, 4(1), 12-17.

Adel M, Alousi LA, Salem HA (2005)

Licorice: a possible anti-inflammatory and anti-ulcer drug. AAPS Pharm Sci Tech 6:74-82

Akhtar, M. S.; Akhtar, A. H. and Khan, M. A. (1995).

Anti ulcerogenic effects of Ocimumbasilicum extracts, volatile oils and flavonoid glycosides in albino rats. Int.J. Pharmacog., 30: 97-104

Amponsah, A. S., Golly, M. K., Sarpong, F., Derigubah, B., \&Endeme, M. (2017).

Proximate and sensory evaluation of non-diary probiotic beverages made from tiger-nuts (Cyperus esculentus L.) and soy bean (Glycine max). International Journal of Innovative Food Science and Technology, 1(1), 9-17.

AOAC (2005).

Official Methods of Analysis of AOAC international $18^{\text {th }}$ Ed. Association of Official Analytical Chemists, Washington.

Atta, A. H.; Nasr, S. M. and Mouneir, S. M. (2005).

Anti ulcerogenic effect of some plants extracts. Natural Product Radiance, 4: 258-263.

Belewu, M. A., \&Belewu, K. Y. (2007).

Comparative physico-chemical evaluation of tiger-nut, soybean and coconut milk sources. International Journal of Agriculture and Biology, 5(785), e787.

Bennett A, Clark-Wibberley T, Stamford IF, Wright JE (1980)

Aspirin-induced gastric mucosal damage in rats: cimetidine and deglycyrrhizinated liquorice together give greater protection than low doses of either drug alone. J Pharm Pharmacol $32: 151$.

Carleton, H. M. (1967).

Histological Technique, $4^{\text {th }}$ ed. New York, Oxford University Press.

Da Nagao Y, Sata M, Suzuki H, Tanikawa K, Itoh K, Kameyama T (1996)

Effectiveness of glycyrrhizin for oral lichen planus in patients with chronic HCV infection. J Gastroenterol 31:691-695

Deutch, M. R., Grimm, D., Wehland, M., Infanger, M., \&Krüger, M. (2019).

Bioactive candy: effects of licorice on the cardiovascular system. Foods, 8(10), 495. 


\section{Egypt. J. of Nutrition and Health Vol. 16 No. 1 January (2021)}

EKeanyanwu,R.C.,Njoku,O.U.andOnonogbu,I.C.(2010).

The phytochemical composition and some biochemical effects of Nigernut (Cyperus esculeniusL)tuber.PakistanJouranal of Nuritiyion,9(7):709-715

Gurbuz,I.,Ozkan,A.M.,Yesilada,E.and.Kutsal,O.(2003).

Anti-ulcerogenic activity of some plants used in folk medicine of pinarbasi (kayseri,Turkey).Journal of Ethnopharmacology,101:313-318.

Guyton,A.C.andJohn,E.H.(2006).

Textbook of Medical Physiology.11th Edn. Elsevier Saunders,Phildelphia.P.797

Hajiaghamohammadi, A.A., Zargar, A., Oveisi, S., Samimi, R., \&Reisian, S. (2016).

To evaluate the effect of adding licorice to the standard treatment regimen of Helicobacter pylori. The Brazilian journal of infectious diseases: an official publication of the Brazilian Society of Infectious Diseases, 20 6, 534-538.

Khazaei, M., \&Salehi, H. (2006).

Protective effect of falcaria vulgaris extract on ethanol induced gastric ulcer in rat. Iranian journal of pharmacology \& therapeutics, $5.43-64$

Krichene D, Artieda DA, Zarrouk M, Astiasarán I. (2016).

Review on Cyperus esculentus: from food safety to pharmaco - therapeutics. Int J Pharmacy, $3(1): 211-216$

Kulshreshtha - M., Srivastava, G., \& Singh, M. P. (2017).

Patho physiological status and nutritional therapy of peptic ulcer: An update. Environmental Disease, 2(3), 76.

MaitySV ,Edasiromon IJ and Ganguly DK(1993)

Antiulcer effect of hot water extract of black tea in proceedings of international symposium tea science and human health Calcutta,pp133-136.

MariebE.N and Hoehn K.Human Anatomy(2010)

(Physiology san Franciaco,USA:BenjaminCommings:2020.

Masoomeh MJ, Kiarash G (2007)

In vitro susceptibility of Helicobacter pylori to licorice extract. Iran J Pharm Res 6:69-72.

Mathur, S, Philipose, CS and Ganaraja, B.(2019).

Effect of Aqueous Extract of Liquorice (G. Glabra L) in Treatment of Stress Induced Gastric Ulcer in Wistar Rats. Pharmacog J.,11(6) Suppl:1526-31.

Moayyedi, P., Soo, S., Deeks, J., Delaney, B., Harris, A., Innes, M.,\& Forman, D. (2005). Eradication of Helicobacter pylori forno nulcer dyspepsia. Cochrane Database of Systematic Reviews, (2). 


\section{Ayat, E. Rizk and Akram, M.M. ELanany}

Momeni A, Rahimian G, Kiasi A, Amiri M, Kheiri S. (2014)

Effect of Liquorice versus bismuth on eradication of Helicobacter pylori in patients with peptic ulcer disease. Pharmacognosy Res.;6(4):341-344

Narayan, K. R. A. J.; Sripal Reddy, M. R. and Chaluvadi, D. R. Krishna (2004).

Anti-viral activity of two flavonoids from tanacetummicrophyllum. Antiviral Res., 19: 207 - 16.

Nugroho AE, Wijayanti A, Mutmainah M, Susilowati R, Rahmawati N. (2016)

Gastroprotective effect of combination of hot water extracts of Liquorice(Glycyrrhiza glabra), Pulasari Stem Bark (Alyxiareinwardtii), and Sembung Leaf (Blumea balsamifera) Against Aspirin-Induced Gastric Ulcer Model Rats. J Evid Based Complementary Altern Med.;21(4):NP77-84.

Ottenbacher, R. and Blehm, J., 2015.

An Unusual Case of Licorice-Induced Hypertensive Crisis. South Dakota Medicine, 68(8). 23.

Parmar, NS and Desai, JK (1993).

A review of the current methodology for the evaluation of gastric and duodenal anti ulcer agents. Indian J. Pharmacol. 25: 120 - 135.

Ramamurthy,V.andUmamaheswari,G.(2012).

Anti-ulcer Activity of Nigella sativa against Gastric ulcer in Rats.International journal of Pharmacy and Drug Research,1(1):9-14.

Reeves, G. P.; Nielsen, H. F. and Fahey, C.G. (1993).

AIN-93 purified diets for laboratory rodents: Final report of the American Institute of Nutrition Ad Hoc writing committee on the Reformulation of the AIN-76A rodent diet. J. Nutr., 123: 1939-1951

Reitman, A. and Frankel, S. (1957).

A coloimetric method for determination of serum glutamic oxaloacetic and glutamic pyruvic transaminase. Am. J. Clin., 28: 56-63

Reis NT. Nutrição(2003).

Clínica: Sistema Digestório. Rio de Janeiro: Rubio, 294p.

Scientific Committee on Food.

Opinion of the Scientific Committee on Food on Glycyrrhizinic acid and Its Ammonium Salt; Scientific Committee on Food: Brussels, Belgium, 2003

Shephard, M. D. and Mezzachi, R. D. (1983).

Scientifi and Technical Committee: Technical Report No.8. The collection, preservation, storage and stability of urine specimens for routine clinical biochemical analysis Clin. Biochem. Revs., 4: 61-67..

Snedecor ,G.W. and Cochran,W.G.(1980)

Statistical methods $.7^{\text {th }}$ Ed.,P.420 .lowa state.Univ.Press,Ames,lowa,,USA. 


\section{Egypt. J. of Nutrition and Health Vol. 16 No. 1 January (2021)}

Toneto, M., Oliveira, F., \&Lopes, M. H. (2011).

Evolução histórica da úlcera péptica: da etiologiaaotratamento. Scientiamedica, 21(1), 2330 .

Umerie SC and JN Enebeli(1997).

Malt caramel from the nuts of Cyperus esculentus. J. Bio. Resource Technol., 8: 215-216.

Wittschier N, Faller G, Hensel A. (2009)

Aqueous extracts and polysaccharides from liquorice roots (Glycyrrhiza glabra L.) inhibit adhesion of Helicobacter pylori to human gastric mucosa. J Ethnopharmacol.;125(2):218-23.

Yehiyan, A., Barman, S., Varia, H., \& Pettit, S. (2017).

Short-course high-dose ibuprofen causing both early and delayed jejunal perforations in a non-smoking man. Case Reports, 2017, bcr-2017. 


\section{Ayat, E. Rizk and Akram, M.M. ELanany}

دراسة لمقارنة تأثير الحليب والعرقسوس وحب العزيز على قرحة المعدة في الجرزان

$$
\text { ايات ابراهيم رزق ,اكرم محمد محمد العنانى }
$$

قسم الاغذيه الخاصه و التغذيه رعهد بحوث تكنولوجيا الاغذيه ـ مركز البحوث الزراعيه -الجيزه ـالقاهره

$$
\text { الملخص العربى }
$$

قرحه المعده هي مرض يصيب عددًا كبيرًا من الناس ، وتحدث لأسباب مختلفة بما في ذلك مضادات

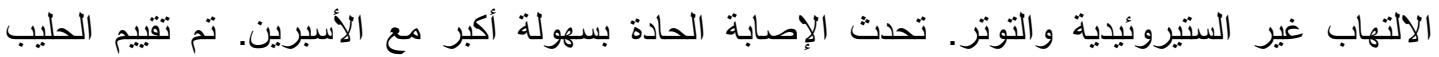

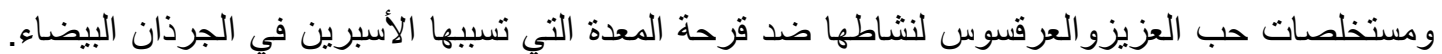

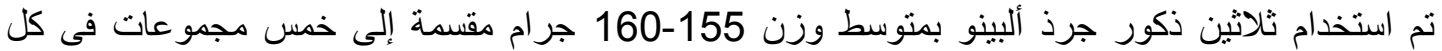

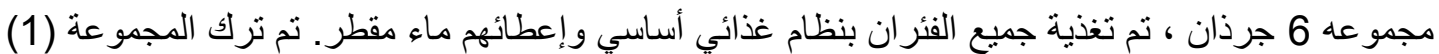

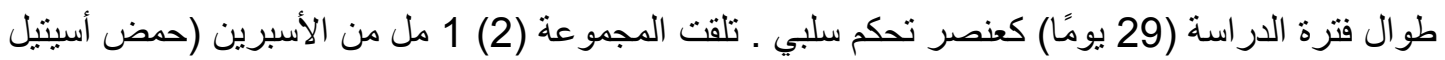

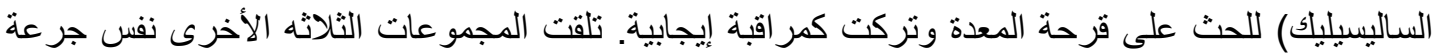

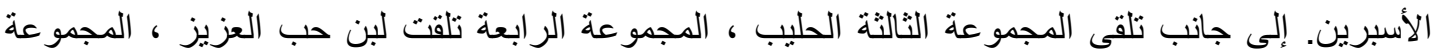

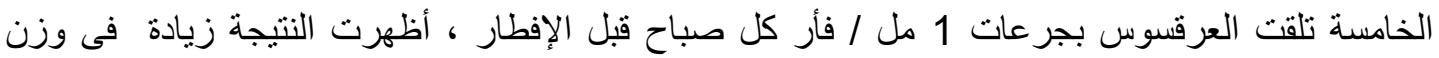

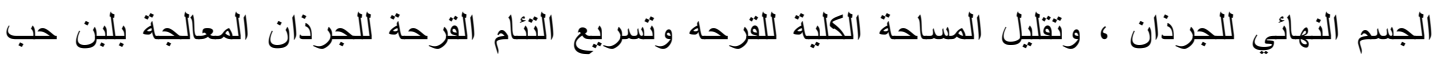

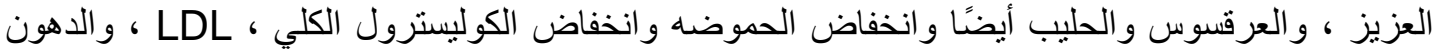

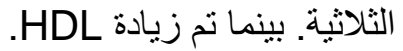

الكلمة الرئيسية. قرحة المعده ، حب العزيز ، العرقسوس ، الحليب 